\section{Preliminary results of hybrid bathymetry and GLOF risk assessment for Neelkanth lake, Lahaul Himalaya, India}

\author{
Sanjay Deswal ${ }^{1, *}$, Milap Chand Sharma ${ }^{2}$, \\ Rakesh Saini ${ }^{3}$, Padma Dalal ${ }^{1}$ and \\ Parmod Kumar ${ }^{1}$
}

${ }^{1}$ Department of Geography, Government College, Dujana, Jhajjar 124 102, India

${ }^{2}$ Centre for the Study of Regional Development, Jawaharlal Nehru University, New Delhi 110 067, India

${ }^{3}$ Department of Geography, Dr Hari Singh Gour Central University, Sagar 470 003, India

In this study, field-based bathymetry of Neenkanth lake in the Lahaul Himalaya, India, was carried out. Volume estimation and calculation of peak discharge, and the results thus obtained have been compared with empirically derived values. Average morphological characteristics of this lake are the depth of $5.78 \mathrm{~m}$, area of $22,925.80 \mathrm{~m}^{2}$ and volume of $132,511.12 \mathrm{~m}^{3}$. The quantitative glacial lake outburst flood (GLOF) characteristics derived from the empirical models were found to be much higher than the measured values of the lake. A qualitative approach was adopted to determine dam breach assessment indicators, viz. dam type, dam geometry, height of the freeboard, etc. GLOF potential was found to be high considering majority of qualitative parameters; however, field measurements indicate a low risk.

Keywords: Bathymetry, dam breach, glacier retreat, lake volume, risk assessment.

THE combination of extremely high relief, high seismic activity and steep slopes in the Himalayan region provides potential sites for a wide range of natural hazards, including landslides, avalanches, flash floods and glacial lake outburst floods (GLOFs) $)^{1}$. The term 'glacial lake outburst flood' is applied to all such events which include a sudden and catastrophic discharge of water from glacierassociated lakes ${ }^{2}$. Many glacial lakes have become unstable due to increase in volume by melting glaciers. Such a scenario can lead to catastrophes when coupled with unsustainable and unplanned growth of infrastructure in the nearby areas ${ }^{3,4}$. GLOF events are reported from all the Himalayan countries, viz. India, Nepal and Bhutan, as a result of climatic changes ${ }^{1,5}$. In June 2013, Chorabari lake in Uttrakhand, India, witnessed a GLOF disaster that caused huge loss to life and property ${ }^{3,6}$. Many researchers have evaluated different glacial lake parameters, e.g. mean depth, potential lowering height and breach width, and formulated empirical equations based on the potential

*For correspondence. (e-mail: sdeswal.jnu@gmail.com) energy of lake volume ${ }^{7-9}$. Based on area of the lake, empirical equations have been proposed for volume calculation $^{4,10}$. However, field-based lake-depth data are missing from the Himalayan region, and therefore, reliability of empirically derived estimates of lake volume and GLOF risk remains completely invalidated. In this communication, we report in-field hybrid bathymetry, in comparison to previously proposed empirical equation assessment for a Himalayan glacial lake.

The GLOF events, however infrequent, are severe geomorphological hazards where floodwaters cause havoc several kilometres downstream. A catastrophic palaeo flood was reported from the Lahaul Himalaya in $1850 \mathrm{~s}$ in River Chandrabhaga that damaged all the bridges ${ }^{11}$, even beyond the present national borders emanating from the Bara Shigri glacier lake breach ${ }^{12}$. The Neelkanth lake $\left(32^{\circ} 45^{\prime} 29.46^{\prime \prime} \mathrm{N}, 7^{\circ} 57^{\prime} 08.78^{\prime \prime} \mathrm{E}\right)$ is located in the Thirot Nala sub-basin of Chandrabhaga in Lahaul-Spiti district, Himachal Pradesh, India. The Lahaul Himalaya has been one of the heavily glaciated areas during early Holocene, and continues to be one of the most significant glacierized areas today ${ }^{13,14}$. The lake is dammed within the left lateral moraine of the major valley glacier (Neelkanth glacier), valley wall and the outer moraine ridge of a small tributary glacier (Figure 1). We used field bathymetry method for volume estimation ${ }^{15}$. The lake depth was measured using a canoe and rope tied with a measuring tape. A metallic fulcrum weighing $400 \mathrm{~g}$ was tied at the end of the rope of measured length, to touch the bottom of the lake, leaving no slack, to assume that it had grounded at the location where dropped. While crossing the lake along the length and breadth, depth was measured at several locations with hand-held GPS tag (Table 1 and Figure 2).

Lateral moraine belonging to an early glacial phase (Figure 1) forms the lake dam with a freeboard of $25 \mathrm{~m}$ (Figure 3). In recent years, there is a continuous retreat of the glacier along with simultaneous thinning. For the

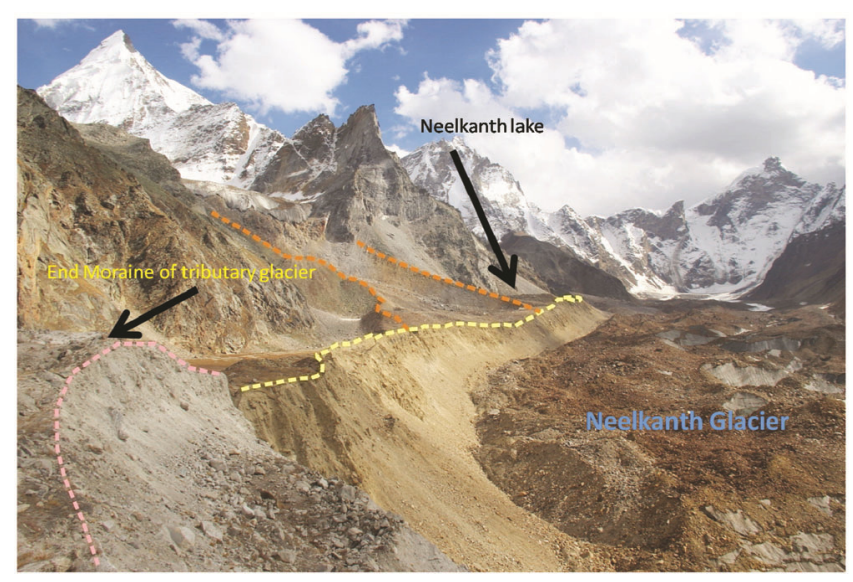

Figure 1. Field photograph showing location of Neelkanth lake and its moraine dams. Relationship of the lake with Neelkanth glacier is also clear from this photograph. 
1989-2002, 2002-2013, and 2013-2019 periods, the average retreat rate was $9.3,4.1$ and $9.1 \mathrm{~m} \mathrm{a}^{-1}$ respectively (the present study). The moraine slope towards the glacier is $\sim 55^{\circ}$, which is considerably high and can be unstable once support of the glacier is removed from its base in this retreating phase (Figure 3). This down-wasting has resulted in a new local base level, a potential for unstabilizing unconsolidated slopes of the lateral moraine enclosing this lake, if the glacier retreat and thinning continue at the present rate. The valley-wall side of the lake having a slope in excess of $70^{\circ}$ is a potential avalanche starting zone (PASZ) ${ }^{16}$. Such steep slopes with evidence of large rock-wall failures on the lake margin also indicate high potential for a mass-mobilized lake instability. Steep lake front area (SLA) in the forefield of the glacier has been defined using threshold angle $\left(10^{\circ}\right)$. Simulation suggests that a gently sloping moraine $\left(<10^{\circ}\right)$ would not initiate a breach, even under a large water inflow ${ }^{17}$. This

Table 1. Measured bathymetry data of Neelkanth lake, Lahaul Himalaya, India

\begin{tabular}{cc}
\hline S1 no. & Depth $(\mathrm{m})$ \\
\hline 1 & 2.3 \\
2 & 5.8 \\
3 & 7.2 \\
4 & 8.4 \\
5 & 9.8 \\
6 & 6.4 \\
7 & 1.8 \\
8 & 1.9 \\
9 & 7.9 \\
10 & 8.7 \\
11 & 3.5
\end{tabular}

Average depth $5.78 \mathrm{~m}$
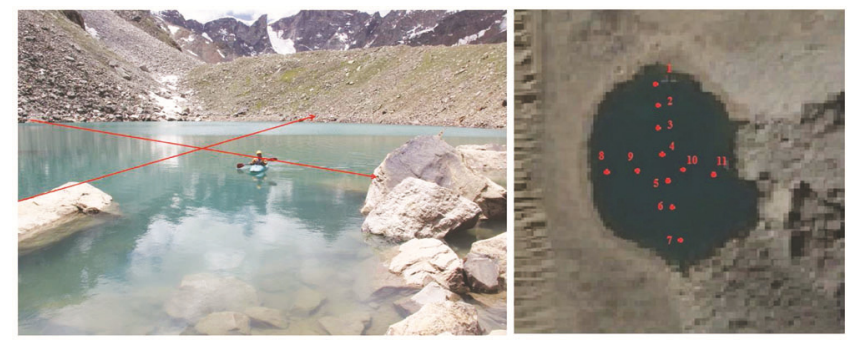

Figure 2. On-field bathymetry measurements using a canoe and points representing location of depth measurements.

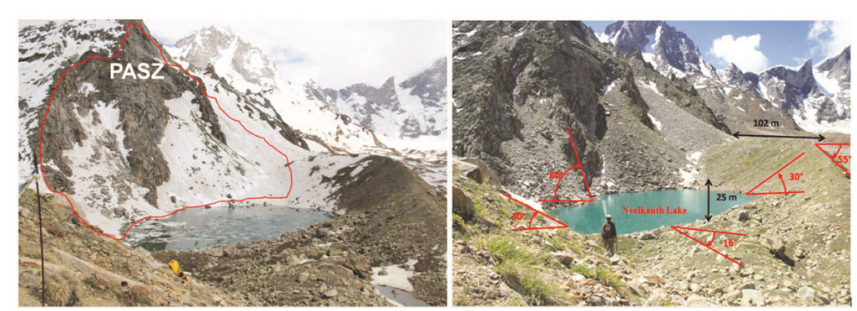

Figure 3. Potential avalanche starting zone at Neelkanth lake and field-based statistics of the moraine dam. also suggests that a glacial lake with no SLA would be unlikely to experience GLOF.

Mean depth of the lake has also been calculated, based on field measurements and area-depth relationship of the Himalayan glacial lakes ${ }^{8}$

$$
D=55 A^{0.25}
$$

where $D$ is the mean depth of the lake (m) and $A$ is its surface area $\left(\mathrm{km}^{2}\right)$.

An empirical relationship based on the Swiss Alps dataset and tested for some of the glacial lakes, including Himalayan lakes, has also been used ${ }^{10}$. This relationship is basically for moraine dammed glacial lakes formed at the lower part of the mother glacier

$$
D=0.140 A^{0.42}
$$

where $D$ is the mean depth of the lake (m) and $A$ is its surface area $\left(\mathrm{m}^{2}\right)$.

Subsequently, peak discharge of the lake was also derived from calculated depth, area and volume of the glacial lake using empirical relations ${ }^{9,18,19}$. The discharge from the lake has been expressed as a function of depth and volume of lake. The most commonly used equations are

Jarrett $^{20}$ :

$$
Q_{\rho}=19.1 D^{1.85} \text {. }
$$

Froehlich $^{21}$ :

$$
Q_{\rho}=0.607\left(V^{0.295} D^{1.24}\right) .
$$

McDonald and Langridge-Monopolis ${ }^{19}$ :

$$
Q_{\rho}=1.154(V D)^{0.412} \text {. }
$$

Based on field measurement, average depth of the lake was $5.78 \mathrm{~m}$, with an area of $\sim 22,925.80 \mathrm{~m}^{2}$ and, volume of $\sim 132,511.12 \mathrm{~m}^{3}$ (Table 2). Physical parameters of target lake are given as Table 2, based on both the field measurements and empirical relations. According to the empirical equation of Fujita et al. ${ }^{8}$ mean depth of the lake is $676.77 \mathrm{~m}$ much higher than measured depth. Similar results were obtained using the method of Huggel $^{10}$ as well, where the mean depth was calculated at $9.49 \mathrm{~m}$, almost 1.64 time the field-based existing depth. Furthermore, discharge from the lake was derived from two empirical methods, and compared with the estimates based on field measurements. These relations are expressed as a function of depth and volume of the lake. The maximum discharge $\left(3,291,163.06 \mathrm{~m}^{3} / \mathrm{s}\right)$ was obtained from the method of Fujita et al. ${ }^{8}$ with a lake depth of $676.77 \mathrm{~m}$, and the minimum discharge from field methods (Table 2). These results underline the fact that 
RESEARCH COMMUNICATIONS

Table 2. Neelkanth lake statistics based on elemental relationship and bathymetric measurements

\begin{tabular}{|c|c|c|c|c|c|c|}
\hline Source & $\begin{array}{c}\text { Lake } \\
\text { area }\left(\mathrm{m}^{2}\right)\end{array}$ & $\begin{array}{c}\text { Mean } \\
\text { depth }(\mathrm{m})\end{array}$ & Volume $\left(\mathrm{m}^{3}\right)$ & $\begin{array}{l}\text { Peak discharge }\left(\mathrm{m}^{3} / \mathrm{s}\right) \\
\quad(\text { from ref. } 20)\end{array}$ & $\begin{array}{l}\text { Peak discharge }\left(\mathrm{m}^{3} / \mathrm{s}\right) \\
\quad(\text { from ref. } 21)\end{array}$ & $\begin{array}{c}\text { Peak discharge }\left(\mathrm{m}^{3} / \mathrm{s}\right) \\
\text { (from ref. 19) }\end{array}$ \\
\hline 8 & & 676.77 & $15,515,493.66$ & $3,291,163.06$ & $259,544.27$ & $15,521.83$ \\
\hline Field investigation & & 5.78 & $132,511.1$ & 490.46 & 173.40 & 306.54 \\
\hline
\end{tabular}

Table 3. Qualitative assessment of Neelkanth lake for glacial lake outburst floods

\begin{tabular}{|c|c|c|c|c|c|c|c|}
\hline \multirow{2}{*}{$\frac{\text { Parameters }}{\text { Dam type }}$} & \multirow[b]{2}{*}{ Lateral moraine } & \multicolumn{4}{|c|}{ Criteria $^{16}$} & \multirow[t]{2}{*}{ Assessed value } & \multirow{2}{*}{$\frac{\text { Possibility }}{\text { High }}$} \\
\hline & & Moraine dam & Ice dam & Rock dam & No dam & & \\
\hline \multirow[t]{2}{*}{ Dam geometry } & Width to height ratio & $>0.5$ & $0.2-0.5$ & $0.1-0.2$ & & $2.5 \mathrm{~m}$ & Low \\
\hline & Free board & $>15$ & $05-15$ & $<5$ & & $10 \mathrm{~m}$ & Medium \\
\hline \multirow[t]{2}{*}{ Triggering factor } & Snow avalanche/rockfall & \multicolumn{2}{|c|}{$\begin{array}{l}\text { Ice/snow avalanche and debris/ } \\
\text { rockfall }\end{array}$} & Yes & No & & High \\
\hline & Colour label & \multicolumn{2}{|c|}{ Low } & \multicolumn{2}{|c|}{ Medium } & \multicolumn{2}{|l|}{ High } \\
\hline
\end{tabular}

for a better assessment of GLOF hazards, detailed field investigation is must rather than relying on empirical methods. We suggest that only empirical method-based GLOF assessment for the Western Himalaya is fraught with very high overestimations and may yield a completely wrong scenario. Based on the criteria for GLOF risk assessment ${ }^{16}$, which includes dam type, dam geometry and existence of triggering factors, Table 3 gives potential GLOF assessment for Neelkanth lake. Although the possibility of GLOF is very high considering majority of other parameters, the actual risk is certainly low as inferred from the results based on field measurements.

1. Richardson, S. D. and Reynolds, J. M., An overview of glacial hazards in the Himalayas. Quaternary Int., 2000, 65-66, 31-47.

2. Ives, J. D., Shrestha, R. and Mool, P., Formation of glacial lakes in the Hindu Kush Himalayas and GLOF risk assessment, ICIMOD, Kathmandu, Nepal, 2010.

3. Dobhal, D. P., Gupta, A. K., Mehta, M. and Khandelwal, D. D., Kedarnath disaster: facts and plausible causes. Curr. Sci., 2013, 105, 171-174.

4. Sakai, A., Glacial lakes in the Himalayas: a review on formation and expansion processes. Global Environ. Res., 2012, 16, 23-30.

5. Aggarwal, S., Rai, S. C., Thakur, P. K. and Emmer, A., Inventory and recently increasing GLOF susceptibility of glacial lakes in Sikkim, Eastern Himalaya. Geomorphology, 2017, 295, 39-54.

6. Bhambri, R. et al., Devastation in the Kedarnath (Mandakini) Valley, Garhwal Himalaya, during 16-17 June 2013: a remote sensing and ground-based assessment. Nat. Hazards, 2016, 80, 1801-1822.

7. Mehta, M., Shukla, T., Bhambri, R., Gupta, A. K. and Dobhal, D. P., Terrain changes caused by the 15-17 June 2013 heavy rainfall in the Garhwal Himalaya, India: a case study of Alaknanda and Mandakini basins. Geomorphology, 2017, 284, 53-71.

8. Fujita, K. et al., Potential flood volume of Himalayan glacial lakes. Nat. Hazards Earth Syst. Sci., 2013, 13, 1827-1839.

9. Froehlich, D. C., Predicting peak discharge from gradually breached embankment dam. J. Hydrol. Eng., 2016, 21, 04016041.

10. Huggel, C., Kääb, A., Haeberli, W., Teysseire, P. and Paul, F., Remote sensing based assessment of hazards from glacier lake outbursts: a case study in the Swiss Alps. Can. Geotech. J., 2002, 39, 316-330.
11. Coxon, P., Owen, L. A. and Mitchell, W. A., A Late Quaternary catastrophic flood in the Lahul Himalayas. J. Quaternary Sci., 1996, 11, 495-510.

12. Chand, P., Sharma, M. C., Bhambri, R., Sangewar, C. V. and Juyal, N., Reconstructing the pattern of the Bara Shigri Glacier fluctuation since the end of the Little Ice Age, Chandra valley, northwestern Himalaya. Prog. Phys. Geogr., 2017, 030913331772801.

13. Deswal, S. et al., Late Holocene glacier dynamics in the Miyar Basin, Lahaul Himalaya, India. Geosciences, 2017, 7, 64.

14. Owen, L. A., Bailey, R. M., Rhodes, E. J. and Holloway, R., Style and timing of glaciation in the Lahul Himalaya, northern India: a framework for reconstructing Late Quaternary palaeoclimatic change in the western Himalayas. J. Quaternary Sci., 1997, 12, 83-109.

15. Fujita, K., Saka, A., Nuimura, T., Yamaguch, S. and Sharma, R. R., Recent changes in Imja glacial lake and its damming moraine in the Nepal Himalaya revealed by in situ surveys and multitemporal ASTER imagery. Environ. Res. Lett., 2009, 4, 1-7.

16. Worni, R., Huggel, C. and Stoffel, M., Glacial lakes in the Indian Himalayas - from an area-wide glacial lake inventory to on-site and modeling based risk assessment of critical glacial lakes. Sci. Total Environ., 2013, 468-469, S71-S84.

17. Westoby, M. J., Brasington, J., Glasser, N. F., Hambrey, M. J., Reynolds, J. M. and Hassan, M. A. A. M., Numerical modelling of glacial lake outburst floods using physically based dam-breach models. Earth Surf. Dyn. Discuss., 2014, 2, 477-533.

18. Das, S., Kar, N. S. and Bandyopadhyay, S., Glacial lake outburst flood at Kedarnath, Indian Himalaya: a study using digital elevation models and satellite images. Nat. Hazards, 2015, 77, 769786.

19. MacDonald, T. C. and Langridge-Monopolis, J., Breaching characteristics of dam failures. J. Hydraul. Eng., 1984, 110, 567-586.

20. Jarrett, R. D., Errors in slope-area computations of peak discharges in mountain streams. J. Hydrol., 1987, 96, 53-67.

21. Froehlich, D. C., Embankment dam breach parameters and their uncertainties. J. Hydraul. Eng., 2008, 134, 1708-1721.

ACKNOWLEDGEMENTS. We thank the Science and Engineering Research Board, Department of Science and Technology, New Delhi for providing financial support. We also thank the Government College, Dujana for providing the necessary facilities to carry out this study.

Received 25 March 2020; revised accepted 8 September 2020

doi: $10.18520 / \mathrm{cs} / \mathrm{v} 119 / \mathrm{i} 9 / 1555-1557$ 